\title{
In vitro maturation of collared peccary (Pecari tajacu) oocytes after different incubation times ${ }^{1}$
}

\author{
Alana A. Borges ${ }^{2}$, Maria V.O. Santos ${ }^{2}$, Luiza B. Queiroz Neta², Moacir F. Oliveira ${ }^{3}$, \\ Alexandre R. Silva ${ }^{4}$ and Alexsandra F. Pereira ${ }^{2 *}$
}

\begin{abstract}
Borges A.A., Santos M.V.O., Queiroz Neta L.B., Oliveira M.F., Silva A.R. \& Pereira A.F. 2018. In vitro maturation of collared peccary (Pecari tajacu) oocytes after different incubation times. Pesquisa Veterinária Brasileira 38(9):1863-1868. Universidade Federal Rural do Semi-Árido, Av. Francisco Mota 572, Mossoró, RN 59625-900, Brazil. E-mail: alexsandra.pereira@ufersa.edu.br

Oocyte in vitro maturation (IVM) is the first step of the in vitro reproductive technologies that enables mature oocytes to be generated ex vivo and after used for embryo production. In this sense, the establishment of culture environment, as oocyte incubation time, is essential for the success of the IVM. Therefore, the study was carried out to investigate the relationship between the meiotic potential and the IVM times of collared peccary oocytes, wild mammals of great commercial and ecological interest. Thus, ovaries were collected of females derived from captivity and transported to the laboratory within 1 hour of slaughtering. The oocytes derived from follicles (3-6mm in diameter) were recovered by aspirated and sliced. Good quality oocytes (evenly granulated cytoplasm with a least one layer of surrounding cumulus cells) were selected and subjected to culture in TCM 199 supplemented with $10 \mu \mathrm{g} / \mathrm{mL} \mathrm{FSH}$, $10 \% \mathrm{FBS}$ and $100 \mu \mathrm{M}$ cysteamine at $38.5^{\circ} \mathrm{C}, 5 \% \mathrm{CO}_{2}$ and maximum humidity for 24 or 48 hours. After the incubation period, the nuclear status, the presence of first polar body and the expansion of cumulus cells of oocytes were assessed. The data obtained were analyzed by Fisher exact test $(\mathrm{P}<0.05)$. A total of four sessions $(2-3$ females per session) were performed, resulting in eighteen aspirated and sliced ovaries with normal morphological characteristics. An oocyte recovery rate of about $83.1 \%(59 / 71)$ was obtained with 3.3 oocytes/ovary and 2.3 viable oocytes/ovary. After different incubation times, differences $(\mathrm{P}<0.05)$ were observed in 24 and 48 hours for expansion of the cumulus cells (38.1\% vs. 100\%), presence of first polar body (52.4\% vs. $90.5 \%)$ and nuclear status in second metaphase $(19.0 \%$ vs. $76.2 \%)$, respectively. In conclusion, 48 hours is suitable time for the in vitro maturation of oocytes derived from collared peccaries when compared to the time of 24 hours, according to the meiotic potential observed. Additional studies should be conducted to improve the quality of the oocyte culture environment, as medium composition, aiming to obtain viable mature oocytes for other in vitro biotechnologies.
\end{abstract}

INDEX TERMS: Collared peccary, Pecari tajacu, oocytes, incubation, reproduction, meiotic competence, nuclear maturation, wild mammals.

\footnotetext{
${ }^{1}$ Received on July 31, 2017.

Accepted for publication on October 18, 2017.

${ }^{2}$ Laboratório de Biotecnologia Animal, Universidade Federal Rural do Semi-Árido (UFERSA), Av. Francisco Mota 572, Mossoró, RN 59625-900, Brazil. *Corresponding author: alexsandra.pereira@ufersa.edu.br

${ }^{3}$ Laboratório de Morfofisiologia Animal Aplicada, Universidade Federal Rural do Semi-Árido (UFERSA), Av. Francisco Mota 572, Mossoró, RN 59625-900.

${ }^{4}$ Laboratório de Conservação de Germoplasma Animal, Universidade Federal Rural do Semi-Árido (UFERSA), Av. Francisco Mota 572, Mossoró, RN 59625-900.
}

RESUMO.- [Maturação in vitro de oócitos de cateto (Pecari tajacu) após diferentes períodos de incubação.] A maturação in vitro (MIV) oocitária é a primeira etapa das tecnologias reprodutivas in vitro que permite que oócitos maturados sejam gerados ex vivo e depois usados para a produção de embriões. Nesse sentido, o estabelecimento do ambiente de cultivo, como o período de incubação de oócitos, é essencial para o sucesso da MIV. Portanto, o estudo foi realizado para investigar a relação entre o potencial meiótico e os períodos 
de MIV de oócitos derivados de catetos, mamíferos silvestres de grande interesse comercial e ecológico. Para tanto, os ovários foram coletados de fêmeas derivadas de cativeiro e transportados ao laboratório dentro de $1 \mathrm{~h}$ após o abate. Os oócitos derivados de folículos (3-6mm de diâmetro) foram recuperados por aspiração e fatiados. Oócitos de boa qualidade (citoplasma uniformemente granulado com pelo menos uma camada circundante de células cumulus) foram selecionados e submetidos ao cultivo em TCM 199 suplementado com $10 \mu \mathrm{g} / \mathrm{mL}$ de $\mathrm{FSH}, 10 \%$ de SFB e $100 \mu \mathrm{M}$ de cisteamina a $38,5^{\circ} \mathrm{C}, 5 \%$ de $\mathrm{CO}_{2}$ e umidade máxima por 24 e 48 h. Após o período de incubação, o estado nuclear, a presença do primeiro corpúsculo polar e a expansão das células do cumulus dos oócitos foi avaliada. Os dados obtidos foram analisados pelo teste exato de Fisher $(\mathrm{P}<0,05)$. Um total de quatro sessões (2-3 fêmeas por sessão) foi realizado, resultando em dezoito ovários aspirados e fatiados com características morfológicas normais. Uma taxa de recuperação oocitária de aproximadamente 83,1\% (59/71) foi obtida com 3,3 oócitos/ovário e 2,3 oócitos viáveis/ovário. Após diferentes períodos de incubação, diferenças $(\mathrm{P}<0,05)$ foram observadas entre 24 e $48 \mathrm{~h}$ para a expansão das células cumulus (38,1\% vs. 100\%), presença de primeiro corpúsculo polar (52,4\% vs. 90,5\%) e estado nuclear na segunda metáfase $(19,0 \%$ vs. $76,2 \%)$, respectivamente. Em conclusão, $48 \mathrm{~h}$ é o período adequado para a maturação in vitro de oócitos derivados de catetos quando comparado ao tempo de 24 h, de acordo com o potencial meiótico observado. Estudos adicionais devem ser conduzidos para melhorar a qualidade do ambiente de cultivo oocitário, como a composição de meio, objetivando obter oócitos maturados viáveis para outras biotecnologias in vitro.

TERMOS DE INDEXAÇÃO: Maturação, oócitos, cateto, Pecari tajacu, incubação, reprodução, competência meiótica, maturação nuclear, mamíferos silvestres.

\section{INTRODUCTION}

Oocyte in vitro maturation (IVM) is the first step of the in vitro reproductive technologies that enables mature oocytes to be generated ex vivo (Rahman et al. 2008) and further destined to systems of in vitro embryo production (IVEP), as in vitro fertilization (IVF), intracytoplasmic sperm injection (ICSI) and somatic cell nuclear transfer (SCNT). All these biotechniques are interesting tools for applying the reproductive management (Kumar et al. 2016) and biodiversity conservation (Moulavi et al. 2017).

The capability of embryonic development depends on successful IVM, since it stimulates the oocyte to achieve the meiotic competence required (Lee et al. 2014) through the nuclear and cytoplasmic events that promote the synthesis of RNA and proteins (Sirard et al. 2006). Therefore, the IVM quality is a determinant factor for the success of the IVEP (Zhang et al. 2015, Park et al. 2017). In this sense, the establishment of culture environment, as oocyte incubation time, should be clarified, once all IVM events require a specific time that could vary according to the peculiarities of each species (Higaki et al. 2017).

The optimization of IVM conditions for collared peccaries is interesting under various concerns. Although this species is not threatened (IUCN 2015), their phylogenetic proximity to endangered species as the Catagonus wagneri (Keuroghlian et al.
2014), as well as the commercial importance on their meat and leather (Nogueira-Filho et al. 2004), have been leading to the development of studies focused on their reproductive physiology (Maia et al. 2014, Miranda-Moura et al. 2016). Based on these studies, it was possible to know that specifically for females, they have symmetrical and oval ovaries with a relatively smooth surface, which can present irregular appearance due to corpus luteum or follicles (Garcia et al. 2009). Moreover, the ovaries are enveloped by an ovarian bursa (Guimarães et al. 2012), as also observed in swine (Męczyński 1974). Additionally, collared peccaries' estrous cycle lasts 21 days, with a follicular phase of 6 days and 15 days for the luteal phase (Maia et al. 2014). On the other hand, these individuals have a lower ovulation rate (2.3 follicles) when compared to swine (Sowls 1997) and usually produce 1.7-1.9 offspring per female after 141-151 days of gestation (Mayor et al. 2005).

Therefore, in view of the need for studies related to the reproductive biotechniques in collared peccaries, the initial point has been to observe reproductive relationship with close domestic phylogenetic species, as swine and others artiodactyls. Thus, similarities were observed for folliculogenesis (Guimarães et al. 2012), hormonal profiles (Ahuja-Aguirre et al. 2017) and follicular histological characteristics (Lima et al. 2013) between collared peccaries and swine and/or artiodactyla species, as buffalos.

In this context, IVM time used for buffalo oocytes is of $24 \mathrm{~h}$ (Kadoom et al. 2014), while maturation time of $48 \mathrm{~h}$ is used for porcine oocytes (Pereyra-Bonnet et al. 2008). Moreover, it had observed that a suboptimal culture environment for porcine oocytes may promote nuclear maturation without the structures reaching cytoplasmic maturation (Abeydeera 2002), confirming that the IVM time to be precise and defined (Sirard et al. 2006). Therefore, this is first study was carried out to investigate the relationship between the meiotic potential and the IVM times of collared peccary oocytes. This information will be the first about the IVM of oocytes derived from collared peccary, aiming to direct pathways to obtain an embryo in vitro of this species. This step can serve as a basis for both enlightening studies of embryogenesis and physiological aspects of the animal. In addition, it may be the starting point for advanced biotechnology that can increase zootechnical potential and ways to ensure effective tools that can be used for conservation of phylogenetically near species.

\section{MATERIALS AND METHODS}

Animal ethics and care. The experiment was conducted in accordance with the Committee for Ethics in Animal Use of Federal Rural University of Semi-Arid (CEUA/UFERSA, no. 23091.001072/2015-92) and the Chico Mendes Institute for Biodiversity Conservation (ICMBio, no. 48633-2). The Pecari tajacu (Linnaeus, 1758) used in this research belong to the Centre of Multiplication of Wild Animals (CEMAS/UFERSA, Mossoró, RN, Brazil, 5¹0’S, 37²10'W), registered at the Brazilian Institute of Environment and Renewable Natural Resources (IBAMA) as a scientific breeding site (no. 1478912). The breeder contains 200 collared peccaries on average. Annually, a programmed slaughter is conducted for population control and the biological material is destined for several experiments.

Reagents and media. All reagents and media used were obtained from Sigma-Aldrich (St. Louis, MO, USA), but fetal bovine serum (FBS) was obtained from Gibco-BRL (Carlsbad, CA, USA). When 
necessary, the $\mathrm{pH}$ was adjusted to 7.2-7.4 for all media. Media were filtered using $0.22 \mu \mathrm{m}$ system (Corning, NY, USA).

Oocyte collection, selection and in vitro maturation. Ovaries were obtained from nine adult female collared peccaries (age 4-10 years). Eighteen ovaries were removed from the ovarian bursa and transported to the laboratory in $0.9 \%(\mathrm{w} / \mathrm{v}) \mathrm{NaCl}$ solution at $37^{\circ} \mathrm{C}$ for up to $1 \mathrm{~h}$. Antral follicles (3-6 mm) were aspirated with 21 gauge needle attached to a $5.0 \mathrm{~mL}$ syringe. After the aspiration, for a greater oocyte recovery, ovaries were sliced with a scalpel blade in 100x20 mm plates. All follicular fluid was pooled in conical tubes for ten minutes. The sediment was diluted in the oocyte collection medium composed of TCM 199 culture medium (M2520) supplemented with $2.2 \mathrm{~g} / \mathrm{L}$ bicarbonate (S5761), $0.2 \mathrm{mM}$ sodium pyruvate (P45622), 1\% antibiotic-antimycotic solution (A5955) and $10 \%$ FBS (12657-029). Thus, cumulus-oocyte complexes (COCs) were selected according to the number of cumulus cells layers and homogeneity of the cytoplasm, being classified in four grades. Grade 1 (3-5 cumulus cells layers and homogeneous cytoplasm); Grade 2 (1-2 cumulus cells layers and homogeneous cytoplasm); Grade 3 (partially denuded cytoplasm and slightly heterogeneous); Grade 4 (denuded and heterogeneous cytoplasm), according to Kumar et al. (2016). Only grade 1 and 2 COCs were considered viable to be matured.

After three washes in oocyte collection medium, the COCs were incubated in $100 \mu \mathrm{L}$ drops of maturation medium composed of TCM 199 with $2.2 \mathrm{~g} / \mathrm{L}$ bicarbonate, $0.2 \mathrm{mM}$ sodium pyruvate, $1 \%$ antibiotic-antimycotic solution and supplemented $10 \mu \mathrm{g} / \mathrm{mL}$ follicle stimulating hormone (Folltropin ${ }^{\circledR}-\mathrm{V}$, Bioniche, Canada), $100 \mu \mathrm{M}$ cysteamine (M9768) and 10\% FBS. All drops were covered with mineral oil and cultured at $38.5^{\circ} \mathrm{C}$ in humidified atmosphere of $5 \%$ $\mathrm{CO}_{2}$ and divided in two groups, 24 and $48 \mathrm{~h}$.

Assessment of in vitro maturation. After the IVM, COCs were evaluated by the analysis of cumulus cells expansion using a stereomicroscope at 20-40x magnification. Thus, oocytes with cumulus cells were considered matured (Appeltant et al. 2015). Subsequently, cumulus cells were removed by pipetting the oocytes in oocyte collection medium and denuded structures were verified for the presence of the first polar body under stereomicroscope at 20-40X magnification. Thus, oocytes with first polar body were considered matured (Pereyra-Bonnet et al. 2008).

The nuclear status of oocytes was determined by marking it with Hoechst 33342 (B2261). For this, denuded oocytes were fixed in paraformaldehyde buffered in $4 \%$ phosphate buffered solution (PBS) for $30 \mathrm{~min}$ and then washed in PBS with $0.4 \%$ bovine serum albumin (BSA). Afterward, Hoechst $33342(10 \mu \mathrm{g} / \mathrm{mL})$ labeling was performed for 15 min and exposed under UV light in fluorescence microscope. Finally, oocytes presenting nucleus in metaphase II (metaphase plate, MII) were considered matured and those in other nuclear phases (prophase I, metaphase I, anaphase I and telophase I) were considered immature (Appeltant et al. 2015).

Data analysis. Data were obtained from four sessions, with 2-3 females per session, totaling in nine experimental animals. For statistical analysis, the Graphpad Instat 3.06 software (GraphPad Software Inc., La Jolla, CA, USA) was used. Mean numbers in percentage \pm standard error of the matured oocytes in two different times (24 vs. $48 \mathrm{~h}$ ) were compared using Fisher exact test $(\mathrm{P}<0.05)$ for expansion of cumulus cells, presence of the first polar body and nuclear status.

\section{RESULTS}

Under gross evaluation, the bursa surrounded all peccaries' ovaries, which were symmetric, presenting an oval shape. Moreover, they had a uniform appearance on most of its surface (Fig.1A); nevertheless, some elevations were observed derived from large follicles or the presence of corpus luteum (Fig.1B).

Afterward all sessions, a total of 18 ovaries resulted in $59 \mathrm{immature}$ oocytes from follicles aspirated and sliced follicles with an estimated recovery rate of $83.1 \%$ (approximately, 59/71; oocytes recovered/follicles aspirated) and 3.3 oocytes per ovary. Of these, 42 structures $(71.2 \%, 42$ structures viable/59 recovered structures) were classified as viable according to the number of cumulus cells layers and homogeneity of the cytoplasm, resulting in 2.3 viable oocytes per ovary, (Fig.2A).

After the IVM, the time of $48 \mathrm{~h}$ was more adequate than $24 \mathrm{~h}$ for the IVM in all evaluated parameters, as cumulus cells expansion $(\mathrm{P}=0.0002)$, presence of the first polar body $(\mathrm{P}=0.0148)$

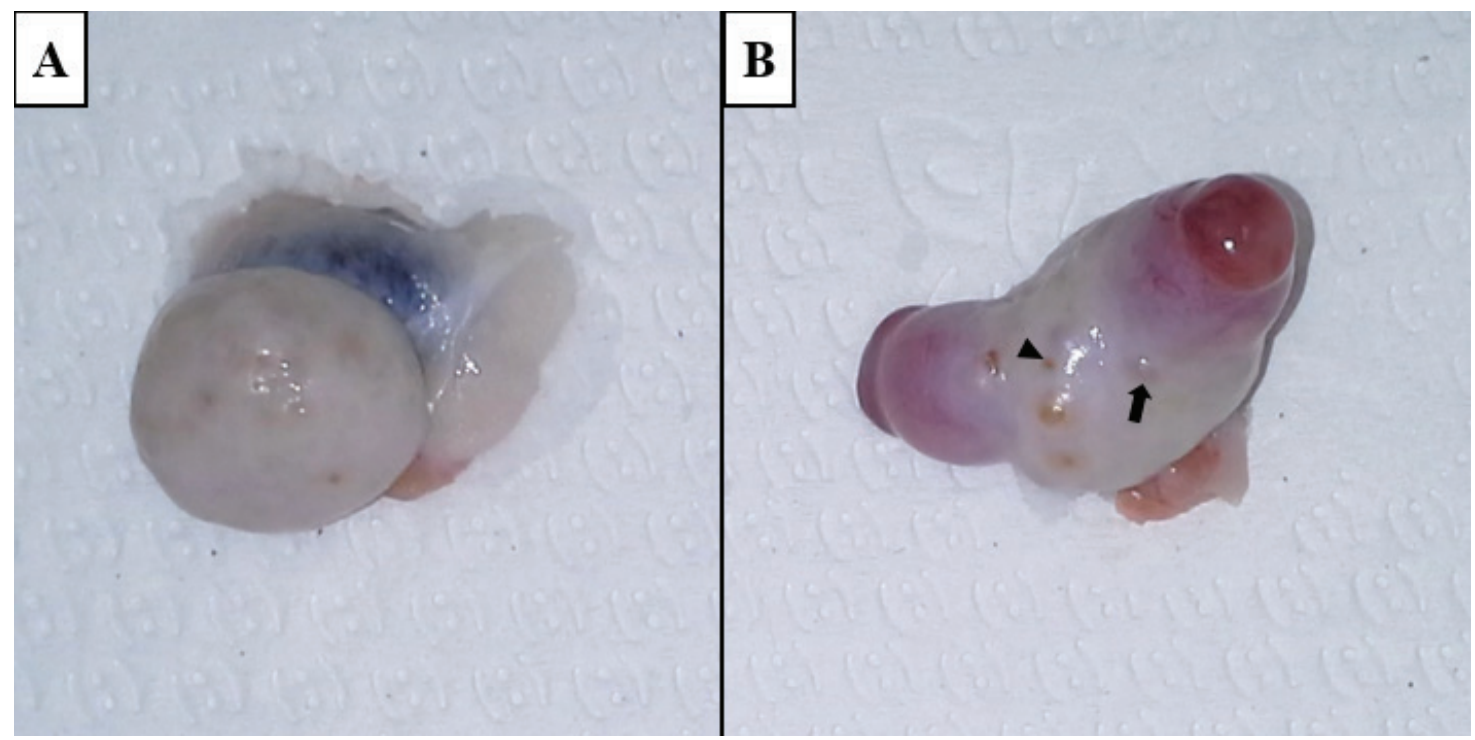

Fig.1. Macroscopic aspects of collared peccary ovaries. (A) Uniform appearance with small follicles. (B) Presence of large follicles and corpus luteum. The arrowhead indicates a small follicle and arrow shows a medium follicle. 


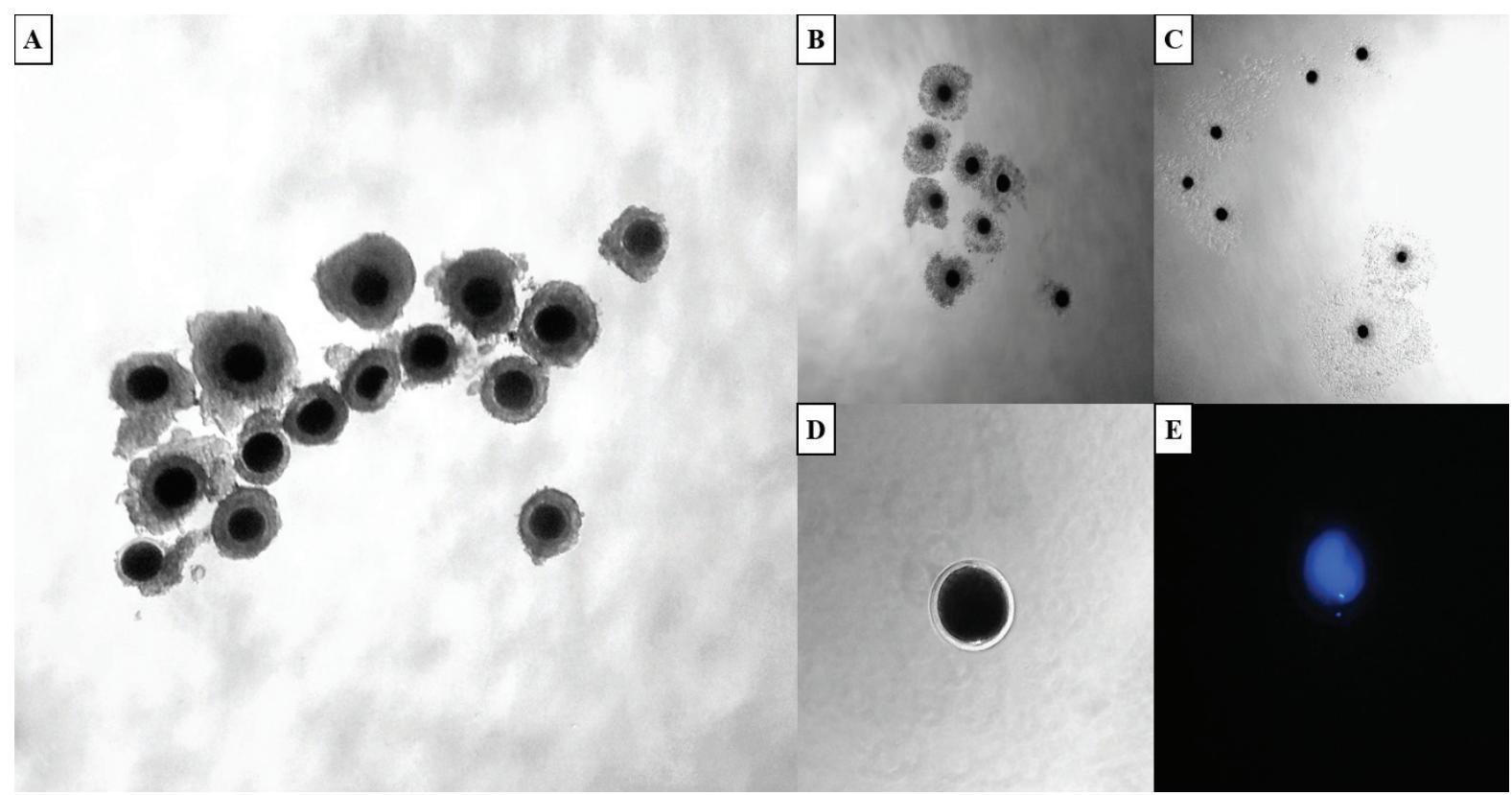

Fig.2. In vitro maturation (IVM) of oocytes of collared peccary. (A) Immature oocytes before IVM. Obj.10x. (B) Cumulus cell expansion after 24 h IVM, Obj.10x. (C) Cumulus cell expansion after 48 h IVM. Obj.10x. (D) Oocyte with extrusion of first polar body. Obj.40x. (E) Oocyte in MII stage. Obj.40x.

Table 1. In vitro maturation of collared peccary oocytes after different incubation times

\begin{tabular}{|c|c|c|}
\hline \multirow{2}{*}{ Evaluation of in vitro maturation } & \multicolumn{2}{|c|}{ Incubation times (in hours) } \\
\hline & 24 & 48 \\
\hline Expansion of cumulus cells & $38.1 \pm 1.4(8 / 21)^{\mathrm{b}}$ & $100.0 \pm 0.0(21 / 21)^{\mathrm{a}}$ \\
\hline Presence of the first polar body & $52.4 \pm 2.2(11 / 21)^{\mathrm{b}}$ & $90.5 \pm 2.0(19 / 21)^{\mathrm{a}}$ \\
\hline Nuclear status in second metaphase & $19.0 \pm 1.4(4 / 21)^{\mathrm{b}}$ & $76.2 \pm 1.3(16 / 21)^{\mathrm{a}}$ \\
\hline
\end{tabular}

Mean in $\% \pm$ standard error $(n) .{ }^{\text {a,b }}$ In same row differ $(\mathrm{P}<0.05)$.

and nuclear status in second metaphase ( $\mathrm{P}=0.0003)$ (Table 1). Moreover, a $100 \%$ cumulus cells expansion was observed for oocytes cultured for $48 \mathrm{~h}$ (Fig.2C) when compared to $24 \mathrm{~h}$ (Fig.2B). Additionally, oocytes with fist polar body (Fig.2D) and MII presence (Fig.2E) were evidenced in more of 50\% and $19 \%$ of the oocytes, respectively.

\section{DISCUSSION}

The results indicated that the most appropriate incubation period for collared peccaries' oocytes achieve meiotic competence was $48 \mathrm{~h}$. This time is similar to that observed for porcine oocytes (Pereyra-Bonnet et al. 2008). In this sense, we can infer that similar follicular characteristics described between collared peccaries and swine (Lima et al. 2013) justify this relationship, since the in vitro conditions for maturation should mimic the in vivo conditions that occur in the females.

Moreover, other peculiar feature of collared peccary oocytes similar to the porcine oocytes is the presence of cytoplasmic lipid droplets (Lima et al. 2013). This aspect is crucial for the establishment of the appropriate requirements for IVM, evidencing that further IVM protocols should be adapted from porcine to peccaries' oocytes. Nevertheless, a factor that still needs to be further investigated by the similarity that collared peccary oocytes had in relation to porcine oocytes is that the IVM in swine oocytes have their altered medium to adapt to the variable requirements of IVM (Grupen 2014) and this step may improve the quality of matured oocytes derived from collared peccaries. Thus, the tracks of such similarities between peccaries and porcine oocytes indicate a starting point, but not the direct application of protocols without further experimentation, considering that differences occur between these species for follicular morphology (Lima et al. 2013).

On the other hand, the follicular development in collared peccaries was also similar to that found for other artiodactyl species regarding the stages of folliculogenesis, i.e. recruitment, selection and dominance (Guimarães et al. 2012) when compared to buffalos (Manik et al. 2002) and camelids (Basiouni 2007). Nevertheless, despite this similarity, the $24 \mathrm{~h}$ IVM time that is frequently used for buffaloes (Kadoom et al. 2014) was not suitable for oocyte maturation in the collared peccaries. The IVM time to guarantee the formation of the metaphase plate is essential to ensure that the oocytes possess the ability to develop quality embryos (Grupen 2014). In this sense, the $24 \mathrm{~h}$ of IVM for collared peccary oocytes was not long enough for the organization of the metaphase plate $(19.0 \%)$, while the majority of oocytes were able to reach metaphase II in $48 \mathrm{~h}$ of IVM (76.2\%). As developmental competence is also reached in cytoplasmic maturation, which occurs after meiotic maturation and refers to the ability of the oocyte to be fertilized and to block polyspermy, this type 
of maturation can be visualized by migration of the cortical granules to the oocyte periphery and by the expansion of cumulus cells (Milakovic et al. 2015). The analysis of cumulus cells expansion at 24 and $48 \mathrm{~h}$ showed different degrees of expansion (38.1\% vs. $100.0 \%$, respectively); these may be related to cytoplasmic maturation, being an indicator of successful maturation (Abeydeera 2002). Therefore, $24 \mathrm{~h}$ of IVM is not sufficient for IVM of collared peccary oocytes (Fig. 2B).

Several important factors for the IVM success are dependent of the incubation time, which can influence the final quality of the embryonic development (Miyoshi et al. 2002). The signaling pathway of 3',5' cyclic adenosine monophosphate (cAMP) is highly time-dependent and restricted to time mechanisms, which is what triggers germinal vesicle breakdown, so nuclear maturation depends on cAMP so the oocyte can reach metaphase II (Sirard et al. 2006). Likewise, another time dependent factor is the secretion of steroid hormones by COCs derived small and large follicles during IVM. Topfer et al. (2016) observed that oocytes derived from small follicles have a lesser ability to support estradiol synthesis in the first half of IVM (28 h) and to suppress progesterone synthesis at the end of IVM ( $48 \mathrm{~h}$ ) compared with oocytes from large follicles. Thus, the steroid hormone secretion by COCs is time-dependent and therefore, the meiotic maturation time should to be precise and defined (Sirard et al. 2006, Topfer et al. 2016).

Moreover, the cumulus cells play a bidirectional role for oocyte development. One of the factors that contribute to this role is their mitochondria and mitochondrial DNA, besides contributing to the passage of nutrients and growth factors to the oocyte (Pawlak et al. 2016). Additionally, it is known that the cumulus cells play a regulatory role for CAMP, showing great relevance for oocyte maturation (Grupen 2014). Therefore, the clear expansion of cumulus cells with $48 \mathrm{~h}$ (Fig. 2C) in this study ensured the optimal performance of the cells during IVM. Further adjustments of cAMP levels during maturation may improve fertilization capacity and oocyte development (Appeltant et al. 2015).

Finally, other factors, as follicles size and technique employed for oocyte collection, may influence the IVM conditions (Sun et al. 2001). In this study, 3-6 mm follicles aspirated and matured for $48 \mathrm{~h}$ allowed the obtaining of oocytes to reach meiotic competence. Moreover, the recovery rate obtained can be due to the use of two methods of oocytes collection, first the follicular aspiration and then the slicing technique. The slicing technique allows the increase oocyte recovery, especially when there is limited availability of ovaries (Ferraz et al. 2016). Moreover, viability rate of $71.2 \%$ can be attributed to the good development of immature oocytes in the follicular environment (Grupen 2014) and the efficiency of the methods for oocyte recovery.

In conclusion, $48 \mathrm{~h}$ IVM for collared peccary is the most suitable incubation period for oocytes reaching the meiotic competence when compared to $24 \mathrm{~h}$ time. This was the first study with in vitro maturation, in an attempt to improve a protocol of IVEP for this species. Although this time has been defined in the present work, further details for the improvement of IVM, as medium composition, should be considered not only to achieve meiotic competence but also to guarantee appropriate embryonic development.
Acknowledgement.- This study was supported by National Counsel of Technological and Scientific Development (CNPq) and Coordination for the Improvement of Higher Education Personnel (CAPES). The authors thank the CEMAS/UFERSA for providing the animals. A.F. Pereira, A.R. Silva and M.F. Oliveira were recipients of CNPq grants.

\section{REFERENCES}

Abeydeera L.R. 2002. In vitro production of embryos in swine. Theriogenology 57(1):256-273. <http://dx.doi.org/10.1016/S0093-691X(01)00670-7> <PMid:11775974>

Ahuja-Aguirre C., López-deBuen L., Rojas-Maya S. \& Hernández-Cruz B.C. 2017. Progesterone and estradiol profiles in different reproductive stages of captive collared peccary (Pecari tajacu) females assessed by fecal metabolites. Anim. Reprod. Sci. 180:121-126. <http://dx.doi.org/10.1016/j. anireprosci.2017.03.008> <PMid:28336266>

Appeltant R., Beek J., Vandenberghe L., Maes D. \& Van Soom A. 2015. Increasing the cAMP concentration during in vitro maturation of pig oocytes improves cumulus maturation and subsequent fertilization in vitro. Theriogenology 83(3):344-352.<http://dx.doi.org/10.1016/j.theriogenology.2014.09.023> $<$ PMid:25442019>

Basiouni G.F. 2007. Follicular wave pattern, folliculogenesis and assisted reproductive techniques in the non-pregnant female dromedary camel (Camelus dromedarius): a review. J. Biol. Sci. 7(6):1038-1045. <http:// dx.doi.org/10.3923/jbs.2007.1038.1045>

Ferraz M.S., Moraes Júnior F.J., Feitosa M.L.T., Almeida H.M., Bezerra D.O., Pessoa G.T., Albuquerque D.M.N. \& Carvalho M.A.M. 2016. Ovarian slicing technique to obtain oocytes from agoutis (Dasyprocta prymnolopha). Pesq. Vet. Bras. 36(3):204-208. <http://dx.doi.org/10.1590/S0100736X2016000300009>

Garcia A.R., Kahwage P.R. \& Ohashi O.M. 2009. Aspectos reprodutivos de caititus (Tayassu tajacu). Revta Bras. Reprod. Anim. 33:71-81.

Grupen C.G. 2014. The evolution of porcine embryo in vitro production. Theriogenology 81(1):24-37. <http://dx.doi.org/10.1016/j. theriogenology.2013.09.022><PMid:24274407>

Guimarães D.A., Garcia S.C.G., Pantoja M.A.F., Silva S.S., Albuquerque N.I. \& Le Pendu Y. 2012. Ovarian folliculogenesis in collared peccary: Pecari tajacu (Artiodactyla: Tayassuidae). Revta Biol. Trop. 60(1):437-455. <PMid:22458237>

Higaki S., Kishi M., Koyama K., Nagano M., Katagiri S., Takada T. \& Takahashi Y. 2017. Early germinal vesicle breakdown is a predictor of high preimplantation developmental competent oocytes in mice. Zygote 25(1):41-48. <http:// dx.doi.org/10.1017/S0967199416000290> <PMid:27873567>

IUCN 2015. Catagonus Wagneri. IUCN Red List of Threatened Species. Version 2015.4. International Union for Conservation of Nature. <http://dx.doi. org/10.2305/IUCN.UK.2015-2.RLTS.T4015A72587993.en>

Kadoom A.K., Abdel-Khalek A.E., Shamiah S.M., El-Sharawy M.E. \& El-Razek I.A. 2014. In vitro maturation, fertilization and development of prepubertal and mature buffalo oocytes. Egyptian J. Anim. Prod. 51:65-69.

Keuroghlian A., Andrade Santos M.D.C. \& Eaton D.P. 2014. The effects of deforestation on white-lipped peccary (Tayassu pecari) home range in the southern Pantanal. Mammalia 79(4):1-7.

Kumar S., Devi B., Purkayastha A., Bharti P.K., Doley S. \& Kadirvel G. 2016. Porcine ovarian biometry, oocyte retrieval and quality of oocytes under different seasons in north east hill region. Indian J. Anim. Sci. 86:300-303.

Lee J., Lee Y., Park B., Elahi F., Jeon Y., Hyun S.H. \& Lee E. 2014. Developmental competence of IVM pig oocytes after SCNT in relation to the shrinkage pattern induced by hyperosmotic treatment. Theriogenology 81(7):974-981.<http:// dx.doi.org/10.1016/j.theriogenology.2014.01.022> <PMid:24576710>

Lima G.L., Santos E.A.A., Luz V.B., Rodrigues A.P.R. \& Silva A.R. 2013. Morphological characterization of the ovarian preantral follicle population 
of collared peccaries (Tayassu tajacu Linnaeus, 1758). Anat. Histol. Embryol. 42(4):304-311. <http://dx.doi.org/10.1111/ahe.12021><PMid:23278244>

Maia K.M., Peixoto G.C., Campos L.B., Bezerra J.A.B., Ricarte A.R., Moreira N., Oliveira M.F. \& Silva A.R. 2014. Estrus cycle monitoring of captive collared peccaries (Pecari tajacu) in semiarid conditions. Pesq. Vet. Bras. 34(11):11151120. <http://dx.doi.org/10.1590/S0100-736X2014001100014>

Manik R.S., Palta P., Singla S.K. \& Sharma V. 2002. Folliculogenesis in buffalo (Bubalus bubalis): a review. Reprod. Fertil. Dev. 14(5/6):315-325. <http:// dx.doi.org/10.1071/RD01126><PMid:12467356>

Mayor P., López-Gatius F. \& López-Béjar M. 2005. Integrating ultrasonography within the reproductive management of the collared peccary (Tayassu tajacu). Theriogenology 63(7):1832-1843.<http://dx.doi.org/10.1016/j. theriogenology.2004.08.007><PMid:15823342>

Męczyński S. 1974. Morphohistological structure of female genital organs in sousliks. Acta Theriologica 19(1/13):91-106. <http://dx.doi.org/10.4098/ AT.arch.74-7> <PMid:4478856>

Milakovic I., Jeseta M., Hanulakova S., Knitlova D., Hanzalova K., Hulinska P., Machal L., Kempisty B., Antosik P. \& Machatkova M. 2015. Energy status characteristics of porcine oocytes during in vitro maturation is influenced by their meiotic competence. Reprod. Domest. Anim. 50(5):812-819. <http://dx.doi.org/10.1111/rda.12592> <PMid:26280917>

Miranda-Moura M.T.M., Oliveira G.B., Peixoto G.C.X., Pessoa J.M., Papa P.C., Maia M.S., Moura C.E.B. \& Oliveira M.F. 2016. Morphology and vascularization of the corpus luteum of peccaries (Pecari tajacu Linnaeus, 1758) throughout the estrous cycle. Arq. Bras. Med. Vet. Zootec. 68(1):87-96. <http://dx.doi. org/10.1590/1678-4162-8486>

Miyoshi K., Rzucidlo S.J., Pratt S.L. \& Stice S.L. 2002. Utility of rapidly matured oocytes as recipients for production of cloned embryos from somatic cells in the pig. Biol. Reprod. 67(2):540-545. <http://dx.doi.org/10.1095/ biolreprod67.2.540><PMid:12135893>

Moulavi F., Hosseini S.M., Tanhaie-Vash N., Ostadhosseini S., Hosseini S.H., Hajinasrollah M., Asghari M.H., Gourabi H., Shahverdi A., Vosough A.D. \& Nasr-Esfahani M.H. 2017. Intespecies somatic cell nuclear transfer in Asiatic cheetah using nuclei derived from post-mortem frozen tissue in absence of cryo-protectant and in vitro matured domestic cat oocytes. Theriogenology 90:197-203.<http://dx.doi.org/10.1016/j.theriogenology.2016.11.023> $<$ PMid:28166968>
Nogueira-Filho S., Nogueira S., Mendes A. \& Jori F. 2004. A large-scale commercial farming of collared peccary (Tayassu tajacu) in north-eastern Brazil. Game Wildl. Sci. 21:413-420.

Park S.J., So K.H. \& Hyun S.H. 2017. Effect of zeaxanthin on porcine embryonic development during in vitro maturation. J. Biomed. Res. 31(2):154-161. <PMid:28808197>

Pawlak P., Chabowska A., Malyszka N. \& Lechniak D. 2016. Mitochondria and mitochondrial DNA in porcine oocytes and cumulus cells: a search for developmental competence marker. Mitochondrion 27:48-55. <http:// dx.doi.org/10.1016/j.mito.2015.12.008><PMid:26705762>

Pereyra-Bonnet F., Fernández-Martín R., Olivera R., Jarazo J., Vichera G., Gibbons A. \& Salamone D. 2008. A unique method to produce transgenic embryos in ovine, porcine, feline, bovine and equine species. Reprod. Fertil. Dev. 20(7):741-749. <http://dx.doi.org/10.1071/RD07172><PMid:18842176>

Rahman A.N.M.A., Abdullah R.B. \& Wan-Khadijah W.E. 2008. In vitro maturation of oocytes with special reference to goat: a review. Biotecnhology 7:599-611.

Sirard M.A., Richard F., Blondin P. \& Robert C. 2006. Contribution of the oocyte to embryo quality. Theriogenology 65(1):126-136. <http://dx.doi. org/10.1016/j.theriogenology.2005.09.020><PMid:16256189>

Sowls L.K. 1997. Javelinas and Other Peccaries: the biology, management and use. Texas A\&M University Press, College Station, Texas, p.86-104.

Sun Q.Y., Lai L., Bonk A., Prather R.S. \& Schatten H. 2001. Cytoplasmic changes in relation to nuclear maturation and early embryo developmental potential of porcine oocytes: effects of gonadotropins, cumulus cells, follicular size, and protein synthesis inhibition. Mol. Reprod. Dev. 59(2):192-198. <http:// dx.doi.org/10.1002/mrd.1022> <PMid:11389554>

Topfer D., Ebeling S., Weitzel J.M. \& Spannbrucker A.C. 2016. Effect of follicle size on in vitro maturation of pre-pubertal porcine cumulus oocyte complexes. Reprod. Domest. Anim. 51(3):370-377. <http://dx.doi.org/10.1111/ rda.12688><PMid:27040379>

Zhang J.Y., Jiang Y., Lin T., Kang J.W., Lee J.E. \& Jin D.I. 2015. Lysophosphatidic acid improves porcine oocyte maturation and embryo development in vitro. Mol. Reprod. Dev. 82(1):66-77. <http://dx.doi.org/10.1002/mrd.22447> <PMid:25564987> 